\title{
WIP An Interview Study of Faculty, Course Assistant, and Student Insight within Teaching and Learning Assistant Programs for Undergraduate Engi- neering Courses
}

\section{Hernán Gallegos, Tufts University}

Hernán Gallegos is currently a junior at Tufts University. He is studying Mechanical Engineering and minoring in Engineering Education. His academic interests lie in trying to aid students to understand engineering concepts and how they can enhance their learning through various resources. With this in mind, he is working within the Engineering Learning Systems lab under Professor Kristen Wendell, a Mechanical Engineering Professor. With this opportunity, Hernán is able to further his understanding of both engineering and education to aid the generations who aim to become future engineers.

\section{Dr. Kristen B. Wendell, Tufts University}

Kristen Wendell is Assistant Professor of Mechanical Engineering and Adjunct Assistant Professor of Education at Tufts University. Her research efforts at at the Center for Engineering Education and Outreach focus on supporting discourse and design practices during K-12, teacher education, and college-level engineering learning experiences, and increasing access to engineering in the elementary school experience, especially in under-resourced schools. In 2016 she was a recipient of the U.S. Presidential Early Career Award for Scientists and Engineers (PECASE). http://engineering.tufts.edu/me/people/wendell/

\section{Dr. Jessica E. S. Swenson, Tufts University, Center for Engineering Education and Outreach}

Jessica Swenson is a graduate student at Tufts University. She is currently pursuing a Ph.D. in mechanical engineering with a research focus on engineering education. She received a M.S. from Tufts University in science, technology, engineering and math education and a B.S. from Northwestern University in mechanical engineering. Her current research involves examining different types of homework problems in mechanical engineering coursework and the design process of undergraduate students in project-based courses. 


\section{Comparing Faculty, Assistant, and Student Insight into Teaching Assistant and Learning Assistant Programs for Engineering Courses}

In undergraduate engineering courses, students typically have access to at least three forms of resources to succeed: online resources, printed literature, and face-to-face help. Face-to-face help is usually with the professor, tutor(s), fellow classmate(s) and instructional assistant(s). Broadly speaking, instructional assistants fall into two main categories: "teaching assistants" (TAs), who typically receive no or minimal pedagogical training or support, and "learning assistants" (LAs), who are often undergraduate students participating in a pedagogy course to build their skills for helping peers learn. Previous work has studied the impact of LA programs on traditional student learning outcomes in STEM subjects ${ }^{[1]}$ and researchers have begun to explore what motivates engineering TAs, ${ }^{[2]}$ but few studies have focused on how relationships are formed between assistants, professors, and students. We are conducting research to explore multiple stakeholders' perspectives on both the TA and LA approaches for instructional assistants in undergraduate engineering courses. In this work-in-progress paper we report our preliminary findings for the following research questions:

RQ1. What do three engineering education stakeholder groups - professors, assistants, and students - report as positive impacts of instructional assistant programs?

RQ2. How do stakeholders from the three groups describe the mechanisms by which assistant programs support learning and course change?

RQ3. What barriers to learning and change do the three stakeholder groups recognize?

\section{Data Collection and Analysis}

For this qualitative descriptive study, data collection consisted of 15 semi-structured interviews with 7 professors, 5 course assistants, and 3 students from 4 different institutions. Out of these 15 participants, 7 were involved with instructional assistant programs that followed a TA model as described above, and 8 were involved with programs that followed an LA model. The goal of recruitment was a maximum variation sample. Ten participants were involved with engineering courses, but we also interviewed 5 participants from other STEM disciplines for later comparison across domains. The semi-structured interview protocol asked participants to recall their experiences with and knowledge about an LA or TA program with which they had been involved. The first author conducted all 15 interviews and frequently prompted for elaboration to elicit deeper meaning. To make the participants feel comfortable during the interview, the interviewer emphasized that the goal was inquiry into their experiences rather than evaluation of their work. ${ }^{[3]}$ Data was collected from a multitude of stakeholders to recognize the diverse relationships that are fostered between stakeholders in different STEM disciplines.

We transcribed all interviews, and both learning and teaching assistantship data were combined. Data analysis followed a grounded theory approach. ${ }^{[4]}$ To begin, the first author conducted open coding at the sentence level to tag perceptions or experiences that appeared to be common across at least two stakeholder groups. Particular attention was paid to the three dimensions suggested by the research questions: descriptions of positive outcomes, mechanisms for change, and 
barriers to ideal implementation. We also looked for participants' mention of relationships built because of assistantship programs. Next, the first author reviewed all tags applied during open coding and used constant comparative analysis to construct and define coding categories that characterized distinct perceptions and experiences. ${ }^{[5]}$ After the second author checked the coding category definitions against data excerpts and refined the definitions, the first author then reviewed all 15 transcripts and re-coded sentences according to the final set of categories as necessary. Finally, for each of the three stakeholder groups, we tabulated the number of participants whose interview responses fell into each coding category.

\section{Results}

We organize our preliminary findings by research question. For each question, we present the categories of perceptions and experiences that emerged from the interviews as common and different across the three stakeholder groups (faculty, assistants, students). At this stage of analysis, we have not found evidence for differing trends between participants from engineering courses and those from courses in other STEM domains, so we collapse those groups in the findings below.

\section{$R Q$ 1. What do three stakeholder groups report as positive impacts of instructional assistant programs?}

\section{Table 1. Positive Outcomes}

\begin{tabular}{|c|c|c|c|c|}
\hline $\begin{array}{l}\text { Category and brief } \\
\text { definition }\end{array}$ & Sample excerpt & $\begin{array}{l}\text { \# of } \\
\text { Professors? }\end{array}$ & $\begin{array}{l}\text { \# of } \\
\text { Assistants? }\end{array}$ & $\begin{array}{l}\text { \# of } \\
\text { Students? }\end{array}$ \\
\hline $\begin{array}{l}\text { Connections } \\
\text { Stakeholders build } \\
\text { relationships with one } \\
\text { another. }\end{array}$ & $\begin{array}{l}\text { "It's really nice when LAs connect with the } \\
\text { students...they really get close with the } \\
\text { students and that's cool to see." (Professor) }\end{array}$ & $7 / 7$ & $5 / 5$ & $3 / 3$ \\
\hline $\begin{array}{l}\text { Development } \\
\text { A stakeholder makes } \\
\text { personal progress while } \\
\text { involved with the program. }\end{array}$ & $\begin{array}{l}\text { "I can be a TA and change the perception [that } \\
\text { people who look like me can't be an engineer]. } \\
\text { But you know, [that perception] is just } \\
\text { something we have, I just use as motivation } \\
\text { moving forward." (Student) }\end{array}$ & $2 / 7$ & $3 / 5$ & $2 / 3$ \\
\hline $\begin{array}{l}\text { Mentorship } \\
\text { There is a sense of guidance } \\
\text { between stakeholders. }\end{array}$ & $\begin{array}{l}\text { "So I think, for me, that's one thing that's really } \\
\text { helpful. Bettering my relationship with the } \\
\text { assistant." (Professor) }\end{array}$ & $6 / 7$ & $4 / 5$ & $3 / 3$ \\
\hline
\end{tabular}

All the stakeholders mentioned how they built a personal connection with another stakeholder or saw that happen between others due to the assistant program. Some saw themselves develop personally during their time with the program, such as better understanding how they learned as a student or noticing how they could leverage their position to change perceptions of who can be a successful engineer. Most professors and assistants, and all students, described the emergence of mentoring relationships in which they could explore issues beyond course content.

RQ2. How do stakeholders from the three groups describe the mechanisms by which assistant programs support learning and course change?

Table 2. Mechanisms for Learning and Course Change 


\begin{tabular}{|c|c|c|c|c|}
\hline Category and brief definition & Sample excerpt & $\begin{array}{l}\text { \# of } \\
\text { Professors? }\end{array}$ & $\begin{array}{l}\text { \# of } \\
\text { Assistants? }\end{array}$ & $\begin{array}{l}\text { \# of } \\
\text { Students? }\end{array}$ \\
\hline $\begin{array}{l}\text { Shared identity } \\
\text { Stakeholders identify other } \\
\text { stakeholders, often } \\
\text { unexpectedly. }\end{array}$ & $\begin{array}{l}\text { "Yes, I have learned to tell people now that I } \\
\text { have been adopted into engineering. So I've } \\
\text { definitely learned a lot more about } \\
\text { engineering than I used to know." (Assistant) }\end{array}$ & $7 / 7$ & $5 / 5$ & $3 / 3$ \\
\hline $\begin{array}{l}\text { Pedagogical training } \\
\text { Stakeholders describe how } \\
\text { pedagogical training } \\
\text { influences assistants. }\end{array}$ & $\begin{array}{l}\text { "I tried to kind of teach that while I was } \\
\text { being a learning assistant. Um, so like when } \\
\text { they're doing a problem and they get stuck, } \\
\text { I'm like, 'Hey, like can you recognize here } \\
\text { why you got stuck?"' (Assistant) }\end{array}$ & $5 / 7$ & $1 / 5$ & $0 / 3$ \\
\hline $\begin{array}{l}\text { Collaborating } \\
\text { Stakeholders realize the } \\
\text { program enables more } \\
\text { collaborative interactions. }\end{array}$ & $\begin{array}{l}\text { "I helped with the interactive part of the } \\
\text { class, helping students while working in } \\
\text { groups to solve problems that were given by } \\
\text { the professor in class." (Assistant) }\end{array}$ & $7 / 7$ & $5 / 5$ & $3 / 3$ \\
\hline $\begin{array}{l}\text { Feelings of intellectual or } \\
\text { emotional support } \\
\text { Stakeholders feel that the } \\
\text { program provides intangible } \\
\text { supports to both learners and } \\
\text { teachers. }\end{array}$ & $\begin{array}{l}\text { "However, if the LAs come to me and say, "I } \\
\text { think we should try this new thing," I will do } \\
\text { everything possible to make that idea } \\
\text { happen." (Professor) }\end{array}$ & $7 / 7$ & $5 / 5$ & $3 / 3$ \\
\hline $\begin{array}{l}\text { Information gathering } \\
\text { Stakeholders describe } \\
\text { opportunities to give or hear } \\
\text { feedback to help improve the } \\
\text { course. }\end{array}$ & $\begin{array}{l}\text { "Then there's I actually had one student } \\
\text { who's a TA and he came in and said I } \\
\text { watched your lecture on op-amps. I learned it } \\
\text { [another] way. [It] might be easier to } \\
\text { understand. I go "that's a great way to teach } \\
\text { it.!" So, I changed it and said this is how } \\
\text { we're teaching it from now on." (Professor) }\end{array}$ & $6 / 7$ & $5 / 5$ & $3 / 3$ \\
\hline $\begin{array}{l}\text { Passionate effort } \\
\text { Stakeholders show surprising } \\
\text { commitment to the work they } \\
\text { do for the course. }\end{array}$ & $\begin{array}{l}\text { "[The teaching assistant] was just [always] } \\
\text { near the students doing work for that class." } \\
\text { (Student) }\end{array}$ & $2 / 7$ & $3 / 5$ & $1 / 3$ \\
\hline $\begin{array}{l}\text { Agency } \\
\text { A stakeholder takes initiative } \\
\text { to accomplish tasks outside of } \\
\text { their job description. }\end{array}$ & $\begin{array}{l}\text { "I've had individual LAs who really step up. } \\
\text { I had an LA who recognized that a short } \\
\text { video demonstrating a technique would } \\
\text { really help everybody, and so he did. He } \\
\text { made his own video, and it's a fantastic } \\
\text { video. It's now up on our lab website and all } \\
\text { our students are required to watch it. It was, I } \\
\text { didn't ask him to do that." (Professor) }\end{array}$ & $6 / 7$ & $4 / 5$ & $2 / 3$ \\
\hline
\end{tabular}

All the stakeholders from all three groups talked about realizing they shared an identity with a different stakeholder, whether it was through engineering, race, gender, or another common characteristic or interest between the stakeholders. Interestingly, most of the professors (all of those involved with LA programs) but only one assistant (also from an LA program) mentioned that pedagogical training positively influenced their practices with students or their own intellectual lives on campus. Presumably this is because three of the five assistants were from TA programs that did not offer pedagogical training and because the student stakeholders were not aware of pedagogical training. All the participants mentioned some form of collaboration benefitting learning, and they all described their assistant program as providing emotional or intellectual support to themselves or another stakeholder. 
Another set of themes emerged around how stakeholders saw assistant programs contributing to course change, not just to current student learning. Professors spoke about using assistant programs to help improve their instructional model; they appreciated critical feedback from their assistants. Some stakeholders recounted a moment where an assistant devoted exceptional effort due to their passion for being in the program. Assistants reported experiencing a positive sense of agency and responsibility when they took initiative to help struggling students; professors and students concurred that they had seen assistants go out of their way to offer learning support.

\section{$R Q 3$. What barriers to learning and change do the three stakeholder groups recognize?}

\section{Table 3. Barriers to Ideal Program Implementation}

\begin{tabular}{|c|c|c|c|c|}
\hline $\begin{array}{l}\text { Category and brief } \\
\text { definition }\end{array}$ & Sample excerpt & $\begin{array}{l}\text { \# of } \\
\text { Professors? }\end{array}$ & $\begin{array}{l}\text { \# of } \\
\text { Assistants? }\end{array}$ & $\begin{array}{l}\text { \# of } \\
\text { Students? }\end{array}$ \\
\hline $\begin{array}{l}\text { Logistical challenges } \\
\text { Stakeholders come across } \\
\text { difficulties with the day-to- } \\
\text { day running of the program. }\end{array}$ & $\begin{array}{l}\text { "Well I say the most challenging part is } \\
\text { scheduling." (Professor) }\end{array}$ & $7 / 7$ & $5 / 5$ & $3 / 3$ \\
\hline $\begin{array}{l}\text { Assistants going through } \\
\text { motions } \\
\text { Stakeholders portray some } \\
\text { assistants as simply } \\
\text { "dialing it in" to complete a } \\
\text { lab or recitation session. }\end{array}$ & $\begin{array}{l}\text { "I guess one thing that comes to mind is that in } \\
\text { Chem. 1, it seemed that the grad TA was very } \\
\text { lab focused. And in some, I mean, kind of } \\
\text { similar in the EE courses too. I'd say honestly } \\
\text { it's pretty similar." (Student) }\end{array}$ & $0 / 7$ & $2 / 5$ & $3 / 3$ \\
\hline $\begin{array}{l}\text { Lack of sufficient } \\
\text { resources in assistant } \\
\text { program } \\
\text { Resources are lacking to } \\
\text { help deepen student } \\
\text { learning. }\end{array}$ & $\begin{array}{l}\text { "So they'll do your homework, you can just } \\
\text { copy what's on the board and turn it in and you } \\
\text { get a good grade, but that doesn't necessarily } \\
\text { help you actually understand the concept, } \\
\text { "cause next time you have a similar project, } \\
\text { you're not going to be able to understand how } \\
\text { to solve it." (Assistant) }\end{array}$ & $2 / 7$ & $3 / 5$ & $2 / 3$ \\
\hline $\begin{array}{l}\text { One stakeholder not } \\
\text { feeling supported by } \\
\text { another } \\
\text { Stakeholder reports lack of } \\
\text { expected support from } \\
\text { another. }\end{array}$ & $\begin{array}{l}\text { "I don't know. I just feel that some of them are } \\
\text { a little bit more detached from their jobs than } \\
\text { the undergraduate students who get paid } \\
\text { hourly." (Student) }\end{array}$ & $2 / 7$ & $1 / 5$ & $2 / 3$ \\
\hline
\end{tabular}

Participants also discussed issues that prevented their assistant program from truly contributing to student learning. Participants in all stakeholder groups described challenges due to day-to-day logistics such as scheduling. All the student participants described instances when an assistant was not focused on trying to help the student learn but instead focused on giving them the answer in order to complete a session as efficiently as possible. About half of the participants, some from each stakeholder group, mentioned both a lack of resources and support from other stakeholders within the TA/LA programs.

\section{Discussion}

We interviewed professors, assistants, and students about their perceptions of and experiences with instructional assistant programs in engineering and other STEM courses. We found widespread appreciation for the connections and mentorships that emerge from assistant 
programs, primarily the learning assistant programs, as well as common perceptions that assistant programs support change by enabling at least five things: shared identities, collaboration, feelings of emotional and intellectual support, critique and feedback pathways, and newfound agency and responsibility. We also identified one widespread theme related to barriers to achieving the ideal assistant program: logistical challenges.

These findings are tentative due to small sample size and pending inter-rater reliability outcomes. We plan to conduct additional interviews and further analysis. However, these preliminary findings do reveal the key role that undergraduate-based assistant programs can play in building connections and shared identities between and among stakeholders in a school or department of engineering; this result suggests that a carefully developed assistant program may go a long way to support diversity and inclusion efforts. Future research is needed to explore additional stakeholder experiences with different variations of learning and teaching assistant programs, especially those at institutions with different cultural norms than those sampled for this initial study.

\section{Acknowledgements}

Special thanks to the participants who agreed to be interviewed for this project and generously gave their time and reflections. We would also like to give special thanks to the Louis Stokes Alliance for Minority Participation (LSAMP) and the Bridge to Engineering Success at Tufts (BEST) programs for providing funding support.

\section{References}

1) Otero, V., Pollock, S., \& Finkelstein, N. (2010). A physics department's role in preparing physics teachers: The Colorado learning assistant model. American Journal of Physics. 78, 1218-1224

2) Kajfez, R. L., \& Matusovich, H. M. (2017). Competence, autonomy, and relatedness as motivators of graduate teaching assistants. Journal of Engineering Education, 106(2), 245272.

3) Russ, R. S., Lee, V. R., \& Sherin, B. L. (2012). Framing in cognitive clinical interviews about intuitive science knowledge: Dynamic student understandings of the discourse interaction. Science Education, 96(4), 573-599.

4) Charmaz, K. (2006). Constructing grounded theory: A practical guide through qualitative research. Sage: London.

5) Strauss, A., \& Corbin, J. (1994). Grounded theory methodology. Handbook of qualitative research, 17, 273-85. 